\title{
InPAX OF ADVERTISERS
}

4pi Analysis, Inc (www.4pi.com)

Advanced Microscopy Techniques(www.amtimaging.com).

Ascend Instruments (www.ascendinstruments.com)

CamScan USA (www.camscan-usa.com) .

Carl Zeiss SMT, Inc. (smt.zeiss.com)

EBSciences (ebs@ebsciences.com).

EDAX Inc.(www.edax.com)

E.L.I. Sprl (www.orionmicroscopy.com)

EMPIX Imaging (www.empix.com)

Ernest F. Fullam (www.fullam.com)

FEI Company (www.feic.com)

Gatan Inc. (www.gatan.com)

Geller MicroAnalytical Lab (www.gellermicro.com)

IXRF Systems (www.ixrfsystems.com)

JEOL USA (www.jeol.com)

Lehigh University Short Course (www.lehigh.edu/microscopy)

M.E. Taylor Engineering (www.semsupplies.com)

Materials Analytical Services (MAS) (www.mastest.com)

McCrone Associates, Inc. (www.mccrone.com)
1 McGill University (www.mcgill.ca/minmet/ebeamworkshop ................ 53

39 Meiji Techno America (www.meijitechno.com) ...................................... 45

43 Micro Optics of Florida, Inc. (info@microopticsfl.com) ......................... 17

5 Micro Star Technologies (www. Microstartech.com) ............................ 34

63 Olympus Industrial America (www.olympusmicroimaging.com/mt) .... 9

7, 25 Pacific Nanotechnology (www.pacificnanotech.com)............................. 15

23 Princeton Gamma Tech (www.pgt.com) ............................................... 4

47 Scientific Instruments and Applications (www.sia-cam.com) ............... 29

55 ScopeTronix Quality Products (www.scopetronix.com) ......................... 45

9 SEMTech Solutions (www.semtechsolutions.com .................................... 41

Soft Imaging Systems Corporation (www.soft-imaging.com) ............... 35

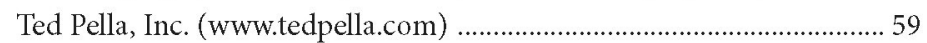

Thermo Electron Corporation (www.thermo.com) ..............................7-27

University of California at Berkeley Workshop ........................................ 61

University of Missouri Short Course ...................................................... 57

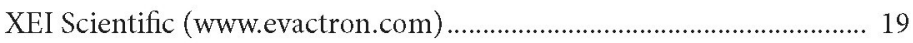

Employment Advertisements

E.A. Fischione, Inc (www.fischione.com) ........................................... 52

University of Alabama .......................................................................... 25

\section{SUBSORIPTION REOUESTS/OHANGES}

\section{Individuals requesting subscriptions, or wishing to change/correct their current address, are requested to do so via our $w w w$ site: \\ http://www.microscopy-today.com SUBSCRIPTION POLICIES}

- Microscopists in Canada, Mexico, and the United States of America are eligible for free subscriptions.

- Microscopy Society of America members receive Microscopy Today as a free member benefit anywhere in the world.

- Non-MSA members, outside North America, may subscribe for $\$ 35$ US per year to cover postage and handling.

- Scanned back issues of MT are available for low-resolution free download on our www site above, after a six-month delay. The entire issues are downloaded-advertisements and all.

- High resolution, CD format, complete volumes are available via airmail for the prices listed below. Note that a volume contains 6 issue for 2002 onwards and 10 issues for 1992 to 2001. Contact editor to order.

Preferred payment is via credit card information when subscribing at the www address. Bank transfer information available from the editor. Checks in US\$, payable to "Microscopy Today," to the editor.

\begin{tabular}{|l|c|c|c|}
\hline \multirow{2}{*}{$\begin{array}{c}\text { Subscription Schedule } \\
\text { Anyone in North America }\end{array}$} & $\begin{array}{c}\text { Current Printed } \\
\text { Issue }\end{array}$ & $\begin{array}{c}\text { Products } \\
\text { Back Issue } \\
\text { Downloaded After } \\
\text { 6-Month Delay }\end{array}$ & $\begin{array}{c}\text { Back Issue Volume } \\
\text { High Resolution CD }\end{array}$ \\
\cline { 2 - 5 } MSA member outside North America & Free & Free Low Resolution & $\begin{array}{c}\text { MSA member \$20/volume } \\
\text { Non-MSA mbr. \$35/volume }\end{array}$ \\
\hline Non-MSA member, outside North America & Free & Free Low Resolution & \$30/volume \\
\hline
\end{tabular}

